〔日農医誌 51巻 2 号 108 113頁 2002. 7〕

\title{
報告：
}

\section{PL 法施行に基づく院内特殊製剤「人工䯣液」作成の試み}

\author{
高野 真*, 辻桃子*, 常 盤 英 文*
}

当院では，脳神経外科の要望により，院内特殊製剤「人工髄液」を調製することとなっ た。人工髄液とは，人の髄液に類似した組成になるように無菌的に調製した水溶液であ る。薬剤部では，人工髄液の調製にあたり，その安全性を考え，PL 法（製造物責任法） をあらためて見直し, 検討した。PL 法解釈上の製造物の欠陥には, 設計上の欠陥, 製造 上の欠陥，指示・警告上の欠陥等があると考えられている。そこで，それぞれに対応して 調製計画書の作成，調製環境の充実，ラベル及び院内特殊製剂添付文書の作成を行った。 その結果，調製者によらない同品質の製剤化，細菌・埃等の混入の防止，使用法及び調製 法の間違いによる事故防止・情報の一元化による医薬品の適正使用の推進に寄与できた。 薬剤師としてあらためて, PL 法を勉強してきたことを通じて, 調製計画書, ラベル及び 院内特殊製剂添付文書を作成したことは，今後の院内特殊製剂の適正使用を進める上で大 変役立った。今後は, 効果, 副作用, 製剂の改良点等を再評価し, 処方, 調製法へとフィー ドバックし，さらなる人工髄液，院内特殊製剂の適正使用に努めていきたい。

\section{(1)人工髄液 (2)製造物責任法 (3)調製計画書 (4)調製環境の充実}

(5)ラベル及び院内特殊製剂添付文書

\section{緒}

\section{言}

当院では，2000年 4 月に救命救急センターを 開設し, 近隣市町村等から多くの急性期患者の 受け入れを行っている。これにともないクモ膜 下出血等の患者の受け入れも多く，このたび脳 神経外科医の要望により院内特殊製剂「人工䯣 液」を作成することとなった。

人工髄液とは，人の髄液に類似した組成にな るように無菌的に調製した水溶液であり，主 に, 脳神経外科手術術後の脳槽潅流液として用 いられる無菌製剂である。使用法は，脳室につ ないだ管に人工髄液を流し, 出血等で污れた髄 液を背中につないだドレーン等を通して洗い流 すようになっている。

\footnotetext{
* $=306-0433$ 茨城県猿島郡境町2190

茨城西南医療センター病院薬剤部

（受付：2002年 3 月 26 日）
}

人工髄液のオーダーは様々1,2)だが，今回は 脳神経外科医の用意したオーダーを用いた。そ れは，以下の通りである。

$\begin{array}{lr}1 \mathrm{~mol} \text { 塩化カリウム液「シミズ」 } & 8.4 \mathrm{~mL} \\ \text { コンクライト-Ca } & 11.8 \mathrm{~mL} \\ \text { コンクライト-L } & 8.4 \mathrm{~mL} \\ \text { 大塚糖液 } 50 \% & 7.2 \mathrm{~mL} \\ 0.1 \mathrm{~N} \text { 塩酸 } & 30 \mathrm{~mL} \\ \text { 塩化マグネシウム・六水和物 } & 1.2 \mathrm{~g} \\ \text { リン酸二水素カリウム } & 0.77 \mathrm{~g} \\ \text { 注射用水 } & 1,038.2 \mathrm{~mL} \\ \text { 大塚生食注 } & 3,896 \mathrm{~mL} \\ 7 \% \text { イロン注 } & 14 \mathrm{~mL}\end{array}$

（メイロン注は，使用直前に混合） ただし，使用直前には $7 \%$ イロン注 $14 \mathrm{~mL} を$ 加えて, $\mathrm{pH}$ を調製して人工髄液とする。これ は, あらかじめ混合すると炭酸カルシウム塩が 生じ，沈殿するおそれがあるため使用直前の混 
合とした。

しかし，当院ではこのような無菌製剤を作成 した経験はなく，作成にあたり様々な問題があ げられた。そこで，院内特殊製剤が，薬剤師が 作り上げる製造物という観点から，製造物責任 法（PL 法）をあらためて見直し勉強すること にした。

$\mathrm{PL}$ 法とは, 平成 7 年 7 月 1 日に施行された 法律で，製造物の欠陥による損害を，その製造 業者の責任とし，消費者の保護をはかることを 目的としている法律である。その第一条の目的 には「この法律は，製造物の欠陥により人の生 命，身体又は財産に係る被害が生じた場合にお ける製造業者等の損害賠償の責任について定め ることにより，被害者の保護を図り，もって国 民生活の安全向上と国民経済の健全な発展に寄 与することを目的とする」光とある。院内特殊 製凨では，その製品の作成にかかわる薬剤師に まで責任が及ぶことが考えられる。

しかしその反面, PL 法は様々な示唆を我々 に与えていることが分かった。PL 法では，製 造物の欠陥が焦点となるが，その久陥は主に次 の 3 点に分かれると考えられている。それが,
設計上の欠陥，製造上の欠陥，指示・警告上の 欠陥である ${ }^{4)}$ 。当院では，これらを念頭におき 以下のような人工髄液の製剂化をとおして，他 の院内特殊製剂にも参考となりうる製品として の安全性, 適正使用の進め方を考えた。

\section{方法}

製造物の欠陥として，(1)設計上の欠陥，(2)製 造上の欠陥，(3)指示・警告上の欠陥があると説 明したが，当院ではそれぞれに対応し，(1)調製 計画書の作成，(2)調製環境の充実，(3)ラベル及 び院内特殊製剂添付文書の作成を行った。

\section{調製計画書の作成}

調製に用いられる医薬品, 器具・機械, 試薬 類の情報をできるかぎり入手した。それらをも とに調製場所，手技，注意事項等も含めた調製 計画書を作成した。具体的には，試薬の調製を 除きほとんどの過程を無菌室で行うため，調製 を行う場所を特定したり，使用を誤ると危険な 試薬もあるため取り扱いの注意事項等を加えた 詳細な調製計画書を作成した。その一部を図 1 にしめす。

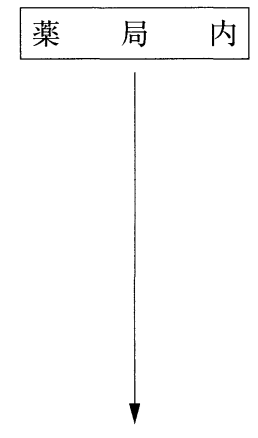

$1 ）$ 塩酸 $(\mathrm{HCl})$ 試薬特級「和光」 $1 \mathrm{~mL}$

腐食性が強く，眼・皮膚・粘膜・肺を刺激し，眼 に接触した場合失明することがある。蒸気の吸入 により咳，たん，潰瘍等を起こすことがあり，又 多量に吸入すると気管支炎, 肺水腫になり死亡す ることがある。飲み込んだ場合には口腔・食堂な どの粘膜を侵し穿孔を生じることがある。

各自マスク，手袋，眼鏡等の防護策を取り，周 りの人にも注意を与える。

$0.1 \mathrm{~N}$ 塩酸 $100 \mathrm{~mL}$

洗浄瓶に予め注射用水を加えて, 全量を $100 \mathrm{~mL}$ にする。

$$
\left\{\begin{array}{l}
\text { メスピペット }(1 \mathrm{~mL}) \\
\text { ゴムピペッター }(50 \mathrm{~mL}) \\
\text { 透明摺りメスフラスコ（100mL) } \\
\text { 広口洗浄瓶 }(500 \mathrm{~mL})
\end{array}\right\}
$$

図 1. 特殊製剂「人工髄液」調製計画書 
参考までに，人工髄液の調製法を記す。

準備として, 調製に用いる器具は原則滅菌し ていなければならない。そこで, 乾熱滅菌, ガ 又滅菌, 高圧蒸気滅菌するものに分けて, あら かじめ滅菌しておく。また，調製に用いるもの はチェックリストをつくり用意する。

具体的な調製は, ドラフトのある所で, 塩酸 (試薬特級「和光」) $1 \mathrm{~mL}$ に注射用水を加え て全量を $100 \mathrm{~mL}$ とする。ここでは，塩酸の性 状として腐食性が強いことと周りの人に注意を 与えることを明記した（図 1 )。

次に, 塩化マグネシウム六水和物（試薬特級 「和光」) $1.2 \mathrm{~g}$, リン酸二水素カリウム（試薬 特級「和光」） $0.77 \mathrm{~g}$ を量り，大塚生食注 3,896 $\mathrm{mL}$ のうちから少量の生食で溶解する。ここで は, 塩化マグネシウムの皮膚刺激性とマスク, 手袋の着用を明記した。

これらの試薬の調製のあと無菌室内において 調製を行う。はじめに作成した塩酸溶液のうち $30 \mathrm{~mL} 5,000 \mathrm{~mL}$ のメスフラスコ（メスフラ スコ・スーパーグレード $5 \mathrm{~L}$ 共栓付; 柴田科 学) にいれ, 注射用水 $1,038.2 \mathrm{~mL}$ を加える。 当院では, 注射用水の規格が 2 つるため経済 的な方を明記した。次に塩化マグネシウム, リ ン酸二水素カリウムの溶液を加え, 大塚生食注 $3,896 \mathrm{~mL}$ のうちから少量を用いて共洗いす る。その後, 残りの薬品, 塩化カリウム液, コ ンクライト $\mathrm{Ca}$, コンクライト $\mathrm{L}$, 大塚糖液 $50 \%$ を加える。最後に全量が $5,000 \mathrm{~mL}$ となるまで 大塚生食を加える。その後, チューブポンプ (XX8200115；日本ミリポア）とメンブラン フィルター (ミリパックフィルターユニットミ リパック-20；日本ミリポア）を用いて $500 \mathrm{~mL}$ の瓶（ねじロビン；DURAN）に分注する。こ のとき, 瓶の蓋にあたるシリコンパッキン（M 24-031；KO-437；GL-45）は注射用水で, 瓶 の中はメンブランフィルターを通した人工髄液 で共洗いしてゴミの混入を防ぐよう明記した

(従って， $5 \mathrm{~L}$ 調製しても， $500 \mathrm{~mL}$ ずっ分注 すると， 7 ～8本分となる)。

その後, $105^{\circ} \mathrm{C}, 30$ 分間高圧蒸気滅菌を行う。 滅菌終了後一本は, 当院検査部及び腎センター
の協力で使用時と同様に，7\%メイロン注 14 $\mathrm{mL}$ を加えて組成についての検査を行う。また 出来上がった製品は，ゴミが入っていないかを 肉眼的に観察し，チェックすることにした。

無菌試験については, あらかじめ検査部に依 頼し，報告書を受けることにした。

\section{調製環境の充実}

調製時には，調製計画書をもとに無菌室，ク リーンベンチを用いての作業を積極的に行っ た。但し, 試薬の調製は, 無菌室での調製が難 しいため, 調製後メンブランフィルターを通す ことを条件に，室内で行うこととした。

\section{ラベル及び院内特殊製剤添付文書の作成}

ラベル及び院内特殊製剤添付文書の作成には 他施設での報告がされているが5)，当院におい ても実際に人工髄液が作り上げられた後, その 製郕が適切に使われるように，大きめのラベル 及び院内特殊製剂添付文書を作成した。

ラベルには，脳神経外科手術時の脳槽潅流液 であることを明記した（図 2 )。また，使用直 前に $7 \%$ メロン注を混合し $\mathrm{pH}$ を調整しなけ ればならない。そのため直前に，7\%メイロン 注を混合することと, 混合時の注意と混合後の チェック欄を明記した。その他, 使用上の注 意, 使用期限, 調製日をもとにしたロット番号, $7 \%$ イロン注を混合した後の組成を明記し た。

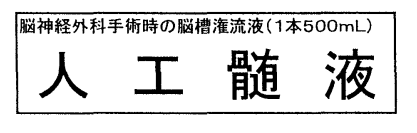

Lot. $01 / 08 / 17 \mathrm{~A}$

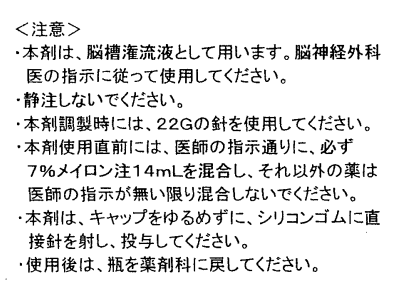

混合時のチェック(混合したら、印をつけてください) $7 \%$ メロン注 $14 \mathrm{~mL}$
使用期限: $2002 / 02 / 17$

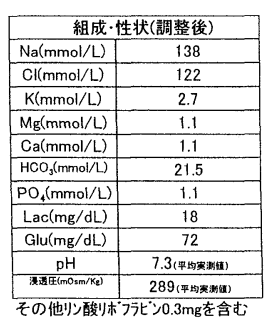

茨城西南医療センター病院 薬剤部 製剂担当
図 2.「人工髄液」ラベル 
表 1 ．院内特殊製剂「人工䯣液」添付文書

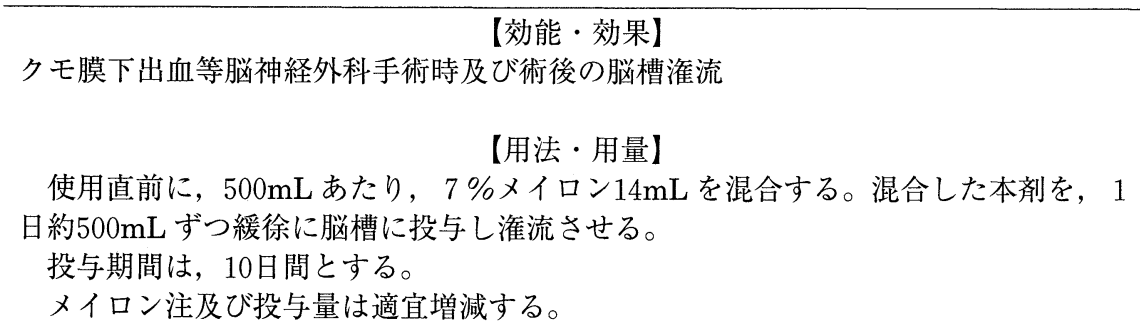

〈用法・用量に関する使用上の注意〉 調製前の本剂を直接投与しないこと

1. 重要な基本的注意

【使用上の注意】

1) 本剂は, 脳槽潅流液としてのみ用いるため静注, 筋注, 内服等はしないでくだ さい。

2 ）本剤を使用するときは，必ず下記の薬剤を混合させて用いること。調製は必ず 使用直前に行う。
$7 \%$
メイロン注
$14 \mathrm{~mL}$

$3 ）$ 上記薬剤での調整後は, 炭酸塩が生成する恐れがあるので, 調製後 2 日経った ものについては使用しないこと。

院内特殊製剤添付文書では, 数種類の医薬品 の添付文書を集め，記載事項を参考にして情報 をまとめた。その一部を示す (表 1 )。記載事 項として選んだ項目は, 添付文書の作成日時, 製品名，作成に至った経緯，警告の項として脳 神経外科医以外の医師の使用の禁止, 組成・性 状, 効能 - 効果, 用法 - 用量, 使用上の注意, 適用上の注意, 処方内容及び薬哓部での調製 法, 調製に用いる薬剂とその規格, 取り扱い上 の注意として貯法・使用期限等を明記した。そ れ以外に一般医薬品では, 副作用, 高齢者・妊 婦・産婦・授乳婦・小児等への投与の項もあっ たが，我々が集めた人工髄液に関する情報の中 にはなかったため，項目をもうけたが具体的な 記載はしなかった。

\section{結 果}

\section{調製計画書の作成}

調製計画書の作成により，大きく2つの結果 が得られた。一つは, 調製者によらない同品質 の製剤化に寄与することができたことである。 すなわち, 調製後の組成に関する検査の結果,
製剤間でのバラツキの少ないことがわかった。 そして，もう一つは，調製者に対する注意を促 し，調製者及び環境への安全性に寄与すること ができた。取り扱う試薬は, 塩酸をはじめ何ら かのかたちで人や器具, 環境へ影響をあたえる ものである。その取り扱いの注意を調製計画書 に盛り込むことにより，調製法のみならず，調 製者や周りの人又は室内環境等への安全性の確 保に寄与することができた。

\section{調製環境の充実}

調製時に積極的に無菌室, クリーンベンチを 用いることにより，埃，ゴミの混入を防ぐこと ができた。

\section{ラベル及び院内特殊製剤添付文書の作成}

大きめのラベルを製品本体に貼付したこと は，実際に使用される病棟の看護婦等にわかり やすいという評価を得た。また, 本剂の存在, 使用法等の知らない医療従事者がいた場合の事 故防止にもつながったと考える。

一方, 院内特殊製剤添付文書の作成では, 人 
工髄液に対する情報をまとめることにより，実 際に日直や当直時に人工髄液を払い出す薬剤部 員の理解への手助けとなり, 又, 医師, 看護婦 等の医療従事者等からの質問に迅速に答えるこ とができ，適正使用を進める上で役立った。

\section{考察}

調製計画書の作成にあたり，人工髄液の調整 法を一つの方法に絞り込んだことは，製剤間の バラツキと製片に関する不信感をなくすことが できた。実際，調製過程において，塩酸溶液を 用意し，そこに直接コンクライト-Lを入れる と，乳酸イオン值が減少もしくは，半分以下に なることがわかった。このように薬品の混合に ついても一つ一つマニュアル化する事は，製剂 の品質の保持にもつながったと考える。また， 情報について医薬品は，適切な情報があるから こそ信頼されうるのである。情報の不足は人工 髄液，院内特殊製剂に対する医薬品としての信 頼が欠けるし，実際になんらかの問題が生じた ときに対応ができないだろう。価值のある情報 を集め，まとめることは，製剤に対する信頼が えられ，自信をもって患者に益するものとして 臨床に製剂をおくることができると考える。

一方，調製環境については無菌室，クリーン ベンチを積極的に利用した。無菌室，クリーン ベンチを用いることにより，埃，ゴミの混入を 防ぐことができた。人工髄液は，無菌であるこ とが一つの条件となっているが，実際には，そ の無菌性を保持するには，このような施設がな ければ不可能であったろう。異物の混入につい ては, 薬品の充填後, 埃やゴミが入っているか の確認を直接行うことができないため, 滅菌 後, 白色光源下で製剂の中を確認し，ゴミの混 入がないかを確認することとした。

ラベル及び院内特殊製剂添付文書の作成で は，主に情報の一元化をはかった。実際に人工 髄液が出来上がっても，これが適正に使用され るか疑問である。医薬品には，様々な剂形，た とえば，内用薬，注射薬，外用薬等いろいろあ る。最近では，使用法も複雑なものもあり，わ かりにくいこともある。特に院内特殊製剂で
は，医師と薬剤師の話し合いで作られるが，実 際に使用するのは患者であり，人工髄液では， 主に看護婦が直前の調製，セッティングを行っ ている現状がある。医療現場に役立つ情報を直 接，医療現場に提供することは，医療事故防 止, チーム医療の叫ばれる中, 我々薬凨師に与 えられた使命であると考え, ラベル及び院内特 殊製剂添付文書を作成した。

人工髄液は一回に使用する量が $500 \mathrm{~mL}$ であ り，大きめのラベルを作成し，必要最低限の注 意事項等を載せることとした。主に使用直前の $7 \%$ \%ロン注の混合に注意を払った。ラベル を充実させることは，必然的に使用する者の目 に止まるようであり，効果があることが解っ た。このことは，他の院内特殊製剂においても 考えさせられる事であった。

院内特殊製剂添付文書は，実際にどれくらい の人たちの目にとまるか不明であるが，少なく ともこれらの情報を設けておくことは，他の医 療従事者等への情報提供と院内特殊製剂の適正 使用に有用であろう。医薬品の適正使用とは, その医薬品が正確に使用された後, 効果や副作 用が評価され，処方にフィードバックされる一 連のサイクルであるとされる5)。今後は，人工 髄液その他院内特殊製剂の使用後の評価も積極 的に行い，そこから得られた知見をラベルや院 内特殊製剤添付文書に反映させ，指示の不備に よる「骝医薬品」とならないようにしていき たいと考えている。

\section{結語}

今回，人工髄液の作成過程から PL 法を勉強 しなおすことにより，より良い製剂化がはから れた。特に調製計画書の作成，ラベル及び院内 特殊製剂添付文書の作成は，同品質の製剂化， 情報の一元化による適切な情報提供と院内特殊 製剂の適正使用に有効であった。この二つの点 は，他の院内特殊製剂の適正使用に向けて活か していく必要がある。

今後は, 使用後の成績による効果, 副作用, 製剤の改良点などを再評価し，処方，調製法へ とフィードバックしていく方法も考え，さらな 
る人工髄液及び院内特殊製剂の適正使用に努め て行きたいと考える。

\section{文献}

1 ) 岡 一成, 朝長正道. 人工髄液. CLINICAL NEUROSCIENCE $1998 ; 16(12): 74-76$.

2 ) 日本病院薬剂師会. 人工䯣液 (No. 19)。病院薬局 製剂第 4 版. 東京：薬事日報社，1997.
3 ) 永井憲一, 室井 力, 利谷信義, 他. 新六法平成 8 年度版. 東京 : 三省堂, 1996.

4) 杉本泰治, 湖上國雄. 製造物責任法一法律家と技 術者とをつなぐ一. 東京：勁草書房, 1996.

5 ) 三川武彦, 吉田廣英, 江戸清人。院内特殊製剂の 直接の容器等への表示内容の検討. 日本病院薬剤 師会雑誌 $1999 ； 35(4): 69-73$.

6 ）厚生省薬務局. 21 世紀の医薬品のあり方に関する 懇談会報告．東京：薬事日報社，1993.

\title{
Attempt to Prepare Artificial Cerebrospinal Fluid in Pursuant to the Product Liability Law
}

\author{
Makoto TAKANO*, Momoko TSUJI* and Hidefumi TOKIWA*
}

At the request of the Department of Neurosurgery, we are providing a special preparation for exclusive use in our hospital. It is artificial cerebrospinal fluid (CSF). The man-made CSF is a solution made similar to human CSF in its composition and is prepared under the aseptic condition. Prior to taking up the task of preparing CSF, we pored over the text of the Product Liability (PL) Law in view of its safety. The defects of products cited by the law included structural defects, functional defects and defects in the way of instructions and caveats. So, a pharmaceutical protocol was drawn out and labels as well as package inserts providing necessary information about the CSF were made. Moreover, we straightened up and improved the workplace environment. All these efforts have resulted in the achievement of homogeneity in the quality of CSF preparations ; protection against bacteria and other contaminants ; prevention of accidents due to the commission of errors in the method of use and preparation; and the promotion of proper use of drugs through unification of information. As pharmacists, we can also say with confidence that we have done much for the right use of other medicines dispensed by us through the preparation of protocols, labels and package inserts after carefully examining the PL law.

\footnotetext{
${ }^{*}$ Dept. of Pharmacy, Ibaraki Seinan Medical Center Hospital, Ibaraki, Japan
} 